\title{
A Paisagem no Diário de Miguel Torga
}

\author{
Tiago Mesquita Carvalho
}

\section{Do Diário ${ }^{1}$}

A primeira entrada do Diário data de 3 de Janeiro de 1932, enquanto a última surge a 10 de Dezembro de 1993. É pois flagrante a aturada regularidade votada a coligir impressões, preocupações e desabafos, pontuais mas significativos. $\mathrm{Na}$ sua brevidade, algumas passagens lembram aforismos pungentes enquanto outras, pela sua extensão, são exposições críticas fundamentadas, que não raro roçam a diatribe ou veredictos, amiúde proféticos, sobre um destino ou identidade pessoal interligado com o estádio corrente da paisagem e da pátria. Todas as entradas são ainda marcadas pela explicitação prévia de um lugar e dia concretos, o que assinala a compreensão dessas descrições nos motivos e contextos geográficos e humanos.

No conjunto dos vários volumes do Diário, é possível arrolar certas cidades, paisagens e aniversários que, na sua recorrência, traduzem uma repetida ritualidade associada à capitalização das vivências ligadas a lugares e a acontecimentos específicos, como é o caso de Coimbra, onde o poeta tinha o seu consultório médico, a povoação transmontana de onde é natural, S. Martinho de Anta, ou os vários miradoiros sobranceiros ao rio Douro; a sua data de nascimento e a véspera de Natal são igualmente marcos que servem o propósito de aferição da vida e do processo de arreigamento de gestos, hábitos e ideias; na sua pluralidade, as diversas demarcações espaciais e temporais demonstram o contínuo périplo da descoberta experiencial de si e do território português que pautaram toda a vida de Miguel Torga ${ }^{2}$.

\footnotetext{
${ }^{1}$ Doravante, as entradas de cada volume do Diário serão assinaladas pelo numeral em itálico e a respectiva página.

2 "Portugal. Foi a procurar entendê-lo que compreendi alguma coisa de mim. As pátrias são espelhos gigantescos onde se reflecte a pequenez dos filhos. À nossa medida, herdamos-lhe a dimensão. E a singularidade.” Cf. XV, 121.
}

Philosophica, 42, Lisboa, 2013, pp. 163-181. 
No que consiste, ao certo, este Diário? Sabendo-o destinado à publicação ântuma, foi portanto necessário ter havido algum critério que saneasse o carácter expositivo das suas entradas ${ }^{3}$; o poeta situa os seus depoimentos num compromisso sincero com os leitores que preserve contudo a sua própria intimidade, sem que haja cedência a quaisquer sentimentalismos ${ }^{4}$; a solidão é pois o limite da salvaguarda desse precioso reduto que absorve e organiza o mundo. A bibliografia exegética do Diário tem-se preferencialmente centrado no acto da escrita como aquele exercício espiritual votado ao auto-conhecimento, que pode ou não implicar a expiação de falhas morais, como cauciona o autor ${ }^{5}$. Para os nossos propósitos, importa salientar como a escrita do eu no Diário implica o reconhecimento e a assimilação de condicionalismos externos que enformam o próprio processo de registo quotidiano, e que assim moldam a consciência de si através da sua progressiva conformação a eles. Não existe um acesso estreme a um eu pré-determinado e do qual o Diário dá conta; trata-se de uma recriação selecta e subjectiva de todo um espectro de vivências que essa epistolografia de si para si acaba igualmente por determinar e sugerir. Como resume Ponce de Leão, "a escrita do eu acaba por não ser uma imitação da vida, para se tornar na própria vida"”.

Nas páginas do Diário pretende-se erigir, pelo esforço e pelo estro, um abrigo do mundo, onde são recriados e apurados os seus momentos mais graves, pulcros e alodiais, mas aos quais é necessário aquilatar o sentido e nessa tarefa edificar o domínio próprio da intimidade que a todos os instantes funda a recriação do mundo e prodigaliza a sua vivência. A este respeito, Peccuci (1994: 125) detalha que "a escrita - metaforicamente entendida também ela como espelho do universo/cosmo - tem um papel de extrema importância não só para comunicar, mas também, sobretudo, para favorecer o processo de gnose e autognose do eu." Processo a que não são de todo alheias as paisagens e os encontros estéticos

3 “Este 'diálogo de si para si', esta dissemelhança entre o eu que viveu os eventos e aquele que sobre eles se debruça, acentua-se e é tanto maior quanto o diário se destina a publicação, o que origina uma reflexão mais profunda sobre o texto". Cf. Monteiro 1994: 345.

4 "Talvez eu me engane a meu respeito e a respeito dos mais. Mas em matéria de revelação da intimidade de cada um, ainda vou pelo diálogo.” Cf. XVIII, 80.

5 "De resto, um diário não é necessariamente um perpétuo mea culpa. Pode ser um simples memento, um exercício espiritual, um caderno de apontamentos, tudo o que se queira. Que nele haja sempre um derrame de pecados e maceração, parece-me um absurdo." Cf. III, 173.

${ }^{6}$ Cf. Leão 2005: 24. Refira-se, no entanto, R. Pereira (1994), Vilela (1994), Lopes (1997) e Leão (2005) como exemplos de comentários ao Diário que alargam o seu horizonte interpretativo para outros temas, como o mito de Anteu, a portugalidade e a natureza. 
com o património natural português ${ }^{7}$, tal como faz questão de enfatizar o poeta $^{8}$. Por conseguinte, deverá tornar-se claro que o Diário não é nenhuma forma de retirar o sujeito à complexidade que o rodeia, nem tampouco um ensimesmamento solipsista que cancele a influência constitutiva do meio envolvente na consciência de si, bem como do corpo e da própria escrita.

Pelo contrário, como assevera Leão (2005: 45), a abertura e a valorização da alteridade percorrem indelevelmente cada volume do Diário:

[...] é por uma sistemática e pertinente atenção ao mundo exterior, pelo envolvimento e empenhamento como com ele se relaciona [...] que, ainda mais uma vez, o Diário de Miguel Torga infringe as leis do género, jamais se circunscrevendo ao interior do eu, mas fazendo este interagir e posicionar-se perante o outro.

Desde os primeiros volumes que Torga reconhece a dificuldade do seu projecto ${ }^{9}$; a vida é una e fragmentá-la em inúmeros registos é desvirtuá-la. A inércia de certas horas a serem formalizadas aflige o poeta enquanto homem e criador ${ }^{10}$, mas é essa resistência indecifrável da simplicidade da vida à escrita que precisamente actua como lenitivo telúrico dos altos voos do espírito e invetera o poeta na sua missão ${ }^{11}$.

\footnotetext{
7 "Olho estes montes circundantes que desde muito cedo me desafiaram a imaginação e as pernas. Os horizontes que deles contemplei é que me balizaram a alma. E agora, que estou no fim, pergunto a mim mesmo o que seria tudo quanto escrevi se eles fossem outros." Cf. XV, 185-186.

8 "Estas paisagens estão de tal modo explicitadas dentro de mim, que parecem escritas no meu entendimento. Quando cuido que estou a interpretá-las, estou a ler-me." Cf. X, 94.

9 “A vida não é para se escrever. A vida - esta intimidade profunda, este ser sem remédio, esta noite de pesadelo que nem se chega a saber ao certo porque foi assim - é para se viver, não é para se fazer dela literatura.” Cf. I, 27-28.

10 "Chego, acendo a lareira, aninho-me no sofá, e fico horas infinitas a olhar em silêncio as labaredas, imerso numa bruma de sentimentos a que não consigo dar voz. É aqui que eu sinto com mais pungência que nunca hei-de ter expressão à altura da minha alma." Cf. XV, 165-166.

11 “Cansado de encher laudas de hieróglifos, ergo-me da mesa de trabalho e vou até à janela desanuviar. Quando o espírito patinha na lama das abstracções, não há nada como pôr de lado o óculo oficinal de ver o mundo e contemplar a realidade a olho nu. As pessoas caminham, cumprimentam-se, conversam, sorriem; os pássaros voam, o sol brilha. E tudo naturalmente, livremente, praticamente, sem corda prévia e sem finalidades transcendentes." Cf. X, 101.
} 


\section{Do corpo que se inscreve}

Foi já notado por S. Pereira (2005: 9) a presença no Diário de um apelo simultâneo à errância e ao enraizamento, vector tensional pelo qual as paisagens rurais, pátrias ${ }^{12}$, são lentamente descobertas em périplos, visitas e venturas, e por conseguinte testemunhadas e valorizadas, na tentativa do poeta nelas presenciar e identificar de perto o que têm de mais genuíno e verdadeiro para a vida humana; é este contacto próximo com a ancestralidade comunitária de várias aldeias, com os seus hábitos, falares e património natural que é sublimado em vários trechos como a vivência de uma panaceia, necessária não só para refregar a ameaça à integridade trazida pelo progresso técnico crescente mas, mais fundamental, como outrossim aquela preciosa condição primeva indispensável à autenticidade humana, que aparenta estar em regressão. Erra-se, pois, para detalhar a vera necessidade de um enraizamento.

Ao longo do diário são várias as entradas com referência directa à inevitabilidade ${ }^{13}$ sedutora do caminhar $^{14}$ e ao acesso pormenorizado a paisagens e lugares desconhecidos e inóspitos que ele possibilita. Chorão $(2005,67)$ nota como o Diário é o registo de uma peregrinação que desvela, "por fidelidade ao seu chão e exigência cultural", "lugares ignorados nos itinerários turísticos" e que busca assim "conhecer o país que somos". Podemos dizer que o poeta-andarilho antecipa, pela sua tematização aforística, a tese de Careri (2006: 24-28) sobre o caminhar como acto estético que permite o aparecer do espaço: pelo caminhar dá-se a medição do espaço através do corpo e torna-se possível inaugurá-lo pelos sentidos. Não produzindo signos ou estruturas materiais, caminhar é uma familiarização percepcional que invoca o jogo da multisensorialidade da paisagem para a memória do corpo, alterando-lhe os significados através de uma leitura de paisagens que se inscreve nelas.

Em Torga, calcorrear distâncias não é apenas o modo predilecto de devorar paisagens, pela volúpia sensual que o cansaço produz e pela total entrega corpórea que acarreta ${ }^{15}$; é também um acto terapêutico que visa

12 "Uma pátria é uma constituição espiritual diária alicerçada no natural eterno." Cf. XIII, 37-38.

13 "Chego a uma terra e não resisto: tenho de me meter pelos campos fora, pelas serras, pelos montes;" Cf. II, 49.

14 "De resto, faz parte do meu ritual subir aos altos, sentir a voluptuosidade da fadiga, como diz Unamuno, e depois olhar." Cf. II, 71.

15 "Sou, na verdade, um geófago insaciável, necessitado diariamente de alguns quilómetros de nutrição. Devoro planícies como se engolisse bolachas de água e sal, e atiro-me às serranias como à broa da infância. É fisiológico, isto. 
um despojamento das agruras políticas e sociais associadas a uma cultura portuguesa de meados do século XX especialmente maninha ${ }^{16}$ e de todo a superficialidade que se acumula na vida de todos os dias. Caminhar por lugares não mapeados é uma actualização própria, uma cultura de renovação e da reintegração de si em si mesmo ${ }^{17}$ através do encontro com o fôlego estético da materialidade das $\operatorname{coisas}^{18}$. O poeta perde-se nesses encontros para se sentir superlativo e inveterado. A expansão do eu atingida é descrita em várias entradas através de sínteses com a natureza ${ }^{19}$ ou com Portugal.

Assinale-se que no Diário a língua portuguesa merece especial consideração. Não falamos simplesmente do tratamento que lhe é conferido pelo escritor enquanto matéria literária, e na qual ela adquire as suas próprias características idiossincráticas, tornando-se vernácula, glabra, reticente a galicismos e outras importações e despida de ganga efabulatória; sob a sua pena ela reflecte assim, e declaradamente, a sua austera paisagem nativa na autenticidade que o escritor lobriga na condição rural, tornando-se tão frugal e nua quanto possível ${ }^{20}$. Pelo testemunho próximo da sua origem rude mas variegada, Torga considera a língua portuguesa verdadeiramente apta para gizar a concretude matizada das coisas, mas falaz se desviada para outras elucubrações mais sistemáticas ${ }^{21}$. Noutra

Empanturro-me de horizontes e de montanhas, e quase que me sinto depois uma província suplementar de Portugal.” Cf. VIII, 149.

16 "Mato-me a andar. Mas alguma vida limpa hei-de ter neste emporcalhado tempo português que me coube. E assim tenho-a. Os restolhos escovam-me os pés e a alma de quanta imundície se lhes colou em trinta anos de vasa nacional.” Cf. VIII, 61.

17 "No meu sangue há uma ancestralidade nómada [...] é uma necessidade de caminhar, de devorar léguas, de conhecer terras, de perspectivar o mundo de todos os ângulos. Sinto-me bem a contemplar paisagens novas [...] tenho a impressão de ficar mais dentro da pele, mais de acordo comigo, mais senhor das minhas certezas." Cf. XII, 40.

18 "Talvez sem eu ter consciência disso, cultivo-me assim pelos olhos e pelos pés, no alfabetismo íntimo das cousas, expressivas na sua luz, no seu clima e no seu paralelo particular." Cf. III, 77.

19 "O meu Portugal é sempre de comunhões assim, que me deixam calafrios na memória do corpo e tatuagens indeléveis na carne da alma. Desci nele a todos os abismos e subi a todos os píncaros, na ânsia de uma sintonia total com a natureza natural de que sempre me senti figuração humana.” Cf. XVI, 10.

20 "Dotado de uma grande economia de meios expressivos, passando sempre ao lado da retórica do atavio, para cunhar a frase na desnudez xistosa e ordenada do seu Doiro natal." Cf. Trigo 1994: 9

21 "Língua de cavadores, esta nossa, quanto mais se leva à bigorna, menos presta. Rude, nas mãos de meu pai, a dar o sensorial e o visual, é que ela está bem. De um pitoresco ilimitado, é difícil conceber outra mais apta para exprimir o colorido das 
passagem, coloca o próprio ónus do génio histórico português na sua e nossa condição de nómadas criadores de geografias, realidade assomando na própria língua ${ }^{22}$.

Outro aspecto de proximidade entre escrita e o telurismo de Torga prende-se com os inúmeros tropos e comparações entre o exercício da escrita e as exigentes andanças do autor pelas paisagens pejadas de vales e serranias, lobrigando regatos virgens, descobrindo árvores centenárias orvalhadas ou miradoiros singulares. A criação literária assemelha-se à caminhada, no sentido de que é nessa solidão que a intimidade constitutiva do eu é acendrada através da consciência do desvelo de novas possibilidades literárias ou naturais; parar é cair. A proximidade entre as duas actividades, a de escritor e a de romeiro, não indicia apenas uma familiaridade de processos trajectivos, de ascensão ou queda e de alcance de elevadas perspectivas. A ligação é recíproca e genesíaca, já que são as qualidades desbravadas em tais caminhadas que parecem industriar a feitura de versos ${ }^{23}$.

Noutra relação, o poeta compara o seu processo criativo ao solo das glebas nativas, carecendo de períodos de pousio para que retemperem a sua fertilidade, e as sementes se possam despedir uma outra vez; será então o tempo de o agricultor se desdobrar em artes e cuidados que garantam uma nova colheita substancial ou literária de tão magro chão, desabrochando novas formas ${ }^{24}$.

coisas [...] Sem qualquer experiência psicológica, não tendo até hoje feito nenhuma tentativa larga para abranger com meios próprios a técnica e a filosofia, é uma dor de coração vê-la tropeçar de incerteza e de pavor, à medida que a vida se complica e pede novas formulações. Para pedir pão, serve às mil maravilhas. E nós de pouco mais precisamos." Cf. IV, 92.

22 "Povo de almocreves da terra e do mar, de andarilhos, o nosso génio é todo geográfico. Aqui, ali, além, acolá, atrás, à frente, ao lado, adiante, abaixo, acima, no meio, são como pegadas físicas duma peregrinação que se orienta. Concretizamos o espaço que outros abstraem. A nossa própria língua é um astrolábio de localização.” Cf. VIII, 51.

23 "Poupar o coração... para fazer versos. Mas haverá um verso que valha o panorama que se abrange do alto de S. Domingos? E farei eu versos quando deixar de subir ao cume dos montes?" Cf. VII, 85.

24 "Nasci tão chegado às origens, que até na criação literária sou como as leiras da minha meninice. No fim de cada colheita pareço estéril, maninho, em restolho. Bem teimo. De nada vale. Não me sai um verso. Tenho de deixar vir o tempo das sementeiras. Então, estrumo, lavro, cavo, grado e semeio. E colho depois os frutos do suor. Não os que sonhei, mas os que a terra sáfara consente.” Cf. XIII, 183. 


\section{Do rural telúrico}

O elogio da autenticidade do camponês não é só documentado pelas excursões ao seu terreno e pelo vigor experienciado pelo próprio poeta quando saca de uma enxada. Enquanto médico, Adolfo Rocha travava com os seus doentes diálogos hipocráticos, o que lhe permitia detectar os seus sintomas; se o testemunho daqueles é puerilmente irrestrito, o dos civilizados é caviloso, prenhe em cautelas e suspicaz ${ }^{25}$. A vivência activa e disseminada da paisagem rural que Torga avoca para si, além de impedir o paradoxo da forclusão ${ }^{26}$, permite uma proximidade receptiva à natureza, que instila serenidade e dignidade em todos aqueles que se devotam a retirar dela o sustento.

Nele, a influência de Rousseau vai para além da caminhada como purga e inspiração literária; a alteridade do natural instila a adopção inconsciente de uma seriedade moral que o escritor contrasta com a degradação urbana da probidade ${ }^{27}$. O poeta estava por demais familiarizado com a realidade rural para sequer se permitir a romantizar-lhe o pitoresco $^{28}$ ou a eufemizar-lhe a brutalidade. E no entanto, elogiava-a na sua plenitude espiritual, na sua lisura solene ${ }^{29}$. Em parte, era a virilidade orgulhosa dessa condição que o atraía, a par do contacto esmerado com a natureza e a moral que dela emergia insuflada por um estilo de vida asso-

25 “A civilização tornou quase impossível esse rasgar de trevas, essa entrega total e confiada da alma dorida ao desvelo hipocrático [...] no camponês tudo se passa doutra maneira." Cf. VII, 55.

${ }^{26}$ Conceito avançado por Berque que designa o divórcio entre o labor associado à feitura e utilização de paisagens e o lazer associado à fruição das mesmas paisagens. Cf. Serrão 2011: 204.

27 "Que inautenticidade a de há pouco, e que autenticidade a de agora! É o dom supremo da natureza: dama de grande senhoria, tudo o que vive na sua intimidade se dignifica também. No meio de panoramas de uma só cara, dificilmente a safadeza se atreve a mostrar as duas habituais. Diante de montes que devolvem o eco de cada afirmação, ninguém é capaz de se contradizer. Daí a sensação de pureza e nobreza que nos dão as criaturas rurais, no trabalho ou no ócio.” Cf. VII, 84.

28 "No fundo agradeço a meu pai a sua fidelidade à terra, ao estrume, à pobreza. Há nessa obstinada humildade uma incorruptível nobreza de condição. O convívio diário com camponeses de ficção afasta-nos da compreensão duma realidade humana que só com óculos cor-de-rosa pode ser mistificada.” Cf. VI, 154.

29 "Despeço-me supersticiosamente da paz do planalto em restolho. O sol morre nos confins dos horizontes, as charruas dormitam, cansadas, à beira dos caminhos, manadas de vacas arrastam placidamente o amojo a caminho da ordenha, e o meu silêncio apreensivo como que cumplicia os companheiros numa comunhão cósmica de que não podem imaginar nem a fundura, nem a santidade.” Cf. XVI, 30. 
ciado à simplicidade. Atribuiu-lhe em muitas passagens o núcleo da condição humana, e daí a valorização do rural português ${ }^{30}$.

Não foi só entre as silvas e as belgas da povoação de S. Martinho de Anta a que o poeta se dirigiu para se rejuvenescer, qual Anteu; muitos dos seus périplos destinam-se a documentar as cambiantes antropológicas ainda harmoniosamente inscritas na paisagem e que transportam consigo os valores vivos de um Portugal de antanho. É este telurismo saudosista latente que, segundo Torga, caracteriza para o bem e para o mal a condição portuguesa ${ }^{31}$. O enraizamento humano num espaço e tempo próprios que a ruralidade possibilita é a crença inabalável do poeta numa promessa exequível de uma vida e de um país equilibrados, capazes de se inscreverem e manterem na ordem natural. Tais lugares e paisagens preservam ainda uma escala e um ritmo próprios, enquadrados ainda na lei natural (physis) e não apenas na lei humana (nómos), podendo actuar como referências contrastantes à métrica espácio-temporal abstracta introduzida na mundividência individual através da difusão da alternativa moderna, e que a esvaziou das referências fenoménicas associadas à vivência de tais paisagens e lugares ${ }^{32}$.

A advertência de Torga reconhece e compreende o horizonte ecuménico associado ao projecto técnico, mas questiona se não estaremos nesse programa a abdicar daquilo que nos define e prende à terra ${ }^{33}$. Contra a imparável tecnicização do mundo, que no seu tempo ainda principiava a invadir o quotidiano, propõe um nivelamento estético-ontólogico que conserve ainda o essencial do homem e o acautele contra a sua desumanização ${ }^{34}$. Uma constante do pensamento torguiano é pois o modo como o

30 "Este Portugal é assim: meio natural, meio segregado. O natural é de pedra, duro, onde só o sal das lágrimas e do suor consegue abrir uma cova e plantar uma vide; o segregado é de bosta de gente e de ovelhas, de sargaço e mexilhão, e é roubado aos ribeiros e ao mar. E há quem tenha coragem de parasitar isto!” Cf. III, 77.

31 "Novamente me enterneceu e me desesperou a trágica condição do português, a enlanguescer longe das berças. Porquê? Esse, para se sentir acompanhado pela força tutelar do berço, teria de carregar às costas um cobertor de papa, um cabrito, um molho de silvas e as próprias lajes da lareira." Cf. VI, 63.

32 A caracterização da mesma é referida por Berque. Ver Serrão 2011: 190.

33 “O nosso gritinho de horror diante de qualquer lesma dá bem a perdição a que chegámos. Civilizámo-nos, mas à custa da nossa mais profunda integridade, dispersando-nos nas coisas que fomos desvendando." Cf. II, 129.

34 "Contra o aceleramento da história, um passeio no campo. Não conheço outro antídoto. Diante duma ciência que devora a própria matéria que estuda, ou duma técnica apostada em envergonhar a nossa fisiologia - só há o recurso das hortas. No seio das searas que amadurecem a um ritmo milenário, junto das oliveiras que florescem no seu vagar quando o cio lhes vem, e a olhar o úbere duma vaca com vinte litros de leite lá dentro, os dramas do espírito atenuam-se. Andar às arrecuas 
despojamento do fútil surge como uma possível axiologia, não se cingindo ao burilar da linguagem ${ }^{35}$. Torga inspira-se em S. Francisco de Assis ${ }^{36}$ para vaticinar que o destino humano terá de ser ora um de pobreza consciente, vivida em meio rural ou natural e à imagem do Portugal verdadeiro que recebe a sua apologia ${ }^{37}$, ora outro de integração irremediável no progresso tecnológico como forma sucessiva de manter, prolongando-os, a insaciabilidade do consumo e a progressiva redução da riqueza da esfera experiencial da vida humana.

\section{Da paisagem}

A escrita do eu, relativamente à paisagem, é um processo heurístico que lhe detalha o sentido, mas poderá ela lograr atingi-lo e fixá-lo definitivamente? Neste aspecto, a posição de Torga parece ser ambivalente. O poeta declara que é nos livros que a paisagem é mais verdadeira, o que remete para a escrita auxiliada pela memória como exercício de activação da vivência das paisagens; noutras entradas, surpreendemos o seu reconhecimento de uma sucessão transparente de metáforas entre a dinâmica da paisagem, a impressão visual que ela suscita e ainda o conjunto de palavras que se lhes sucedem ${ }^{38}$. Noutra, fala da paisagem como um esta-

até acertar o passo com esta nossa morosa mãe que se chama natureza, calma senhora que nos olha com a benévola indulgência das mães. As traquinices dos filhos não lhe fazem perder a calma. Só há uma lei: a dela." Cf. VI, 83.

35 "Essa permanente busca implica uma rejeição constante: a do supérfluo. Por isso o seu ideal franciscano de despojamento - na vida individual como na colectiva, na língua pátria como nessa língua própria, individual, que cada poeta acaba sempre por ter." Cf. Lopes 1994: 261

36 "Ou se escolhe como ideal um S. Francisco de Assis a rasgar-se nas silvas e a tratar de tordos, ou não há outro remédio senão a gente integrar-se no movimento universal desta gigantesca máquina moderna, e fazer nela de parafuso, como mostrou Chaplin. Assim divididos, com luz e sombra na alma, vestidos e despidos ao mesmo tempo como frutos mal descascados, é que não. Assim é morrer todos os dias." Cf. I, 198-199.

37 "Cá estou mais uma vez cingido à minha natureza profunda, vestido como qualquer camponês e a sentir-me bem dentro desta pele terrosa, cavo o quintal, arranco silvas, podo roseiras, racho lenha. Sabe bem partilhar da condição comum." Cf. XIV, 31.

38 "Subo ao alto da serra, olho em redor, e até me parece impossível que nas pupilas tão pequenas do homem possam caber certas grandezas. Mas cabem. E mais: é nelas que tais grandezas adquirem sentido. Dessa imagem dinâmica à palavra que a significa, vai um palmo. E a palavra reveladora pode ser o intróito de um verso. E o verso a eterna e ritmada pulsação audível dum imenso e oculto coração de granito.” Cf. X, 57. 
do de alma, sacrificando-a à subjectividade no seu poder para despertar impressões no ânimo, tornando-a dependente das flutuações deste. Cabe porém ao poeta a acuidade de saber vê-la e explorá-la renovadamente ${ }^{39}$, mesmo que devido a repetidas incursões esta cesse de excitar os sentidos. A questão da apreciação de paisagens estar sujeita ao embotamento sensorial por exposição prolongada foi cara a Torga, aludindo à incerteza da causa de tal inconstância para com a natureza se situar na paisagem ou no apreciador $^{40}$. É contudo decisiva, quanto a nós, a entrada mais tardia do Diário, em que o poeta parece dirimir a sua posição ambivalente através de uma revisão da atitude prestada à apreciação da paisagem, mormente através de descrições projectivas, de domínio dissimulado, a que vários autores se prestam; torna-se necessário um afastamento cauto que lhe respeite a integridade, não a deturpando pelo ânimo ou por hermenêuticas, o que não impede de todo um contacto apreciativo apurado ${ }^{41}$. $\mathrm{A}$ intangibilidade da paisagem e do maravilhoso natural, a impossibilidade lógica, mais do que a dificuldade artística, de resumi-los, descrevê-los, encerrá-los num trecho ou mesmo num verso, figura em bastantes passagens do Diário $^{42}$; ao escritor resta a vivência estética desses instantes que, inspirando registos, frustram-nos pela sua pura irradiação ${ }^{43}$.

39 "O que salva o poeta é uma espécie de volubilidade visual, incorrigível. Como nunca vê com olhos automáticos, hirtos, rotineiros, pode, do mesmo ângulo e nas mesmas circunstâncias, estar sempre a descobrir novidades, aspectos inéditos numa paisagem gasta. E é o que me acontece.” Cf. VI, 109.

40 “Ou será que tudo se esgota, não dentro de nós, mas na sua íntima capacidade de induzir admiração? Que a própria magnificência duma paisagem como esta perca o seu magnetismo emotivo, à medida que vive?” Cf. VII, 32.

41 “A paisagem [...] o homem até dela se quis apoderar, proclamando romanticamente que as próprias mutações da natureza dependiam dos seus estados de alma. Num esforço aturado de cura, fui-me libertando progressivamente desse vício deformador, cada vez mais certo de que nunca era eu que fazia falta aos panoramas quando lhes virava as costas, mas eles que me faziam falta a mim. Fico de fora, efémero, a admirar-lhes a eternidade." Cf. XI, 163.

42 "Instalado no pátio, vou lavrando prosa. O ar cheira a pólen, a azálea amarela florida é um sol vegetal, o ninho de melro ainda fumega da procriação, a primavera estala por todas as costuras da vida [...] E paro de escrever. A laboriosa página que me saía da pena mete dó ao lado da página aberta do universo.” Cf. XII, 111.

43 "Não desejo ao meu maior inimigo a incapacidade expressiva que se apodera de mim diante de certas paisagens do mundo. Quero, e não posso ir mais além dum inibido deslumbramento. Era transmitir aos outros o meu próprio êxtase, mostrá-las como as vejo, revelá-las como as entendo. Mas nada disso consigo. Ilumino-as com o íntimo sol da alma, recebo a luz reflectida, e fico cego. E a cegueira dum poeta é a sua mudez." Cf. VIII, 53-54. 
O Diário contém igualmente diversos testemunhos pessoais e documentados de vários acontecimentos recentes que paulatinamente promoveram a transformação irreversível da paisagem portuguesa e que, num âmbito mais abrangente, ilustram e identificam as alterações ontológicas entre o homem e a terra. Nesta óptica, nas suas páginas torna-se evidente o significado que foram para a sensibilidade do poeta os vários sobressaltos históricos como a reflorestação dos baldios serranos ${ }^{44}$, a emigração da povoação rural e o consequente abandono dos campos, a construção das primeiras barragens ${ }^{45}$ e da rede de estradas nacionais e a consequente construção urbanística desenfreada que assolou muitas aldeias remotas e fomentou o turismo de massas.

No território português, como reconhece Torga, as paisagens eram, até há bem pouco tempo, uma síntese bem conseguida da relação entre o homem e a natureza, conservada em grande parte pelo longo e lento trabalho de sedimentação ligado a uma agricultura de subsistência de baixo impacto e produtividade ${ }^{46}$. Mudadas as condições sociais, alterando-se as capacidades técnicas de transformação dos solos e mercantilizando-se os produtos agrícolas, as paisagens alteraram-se na exacta medida da aceleração energética e de escala destes factores que concorriam para a sua manutenção harmoniosa ${ }^{47}$. Constatá-lo é testemunhar uma perda.

É certo que se encontra no Diário a acepção de uma certa fixidez ${ }^{48}$ associada à pátria ${ }^{49}$, que perante as mudanças que a perpassam encontra

44 "A serra Amarela é um dos ermos mais perfeitos de Portugal. Situada entre o Gerês e o Lindoso, as suas dobras são largas, fundas e solenes. Sem capelas e sem romarias, cruzam-na os lobos, os javalis e as corças. A praga dos pinheiros oficiais ainda lá não chegou." Cf. III, 105-106.

45 "Os rios do passado, à solta, davam lirismo. Agora, represados, dão energia eléctrica. Mas a água que fica assim empanturrada [...] simboliza-me um presente sem ilusões e um futuro sem versos. Com muros diante do nosso caminho de anárquica liberdade, teremos todos de descarregar também a energia que possuímos nas turbinas blindadas do útil, alojadas no âmago de uma triste humanidade de individualidades desfeitas.” Cf. VI, 120.

46 " [...] pela graça suplementar da cultura que foi acrescentada à beleza silvestre. Aqui como lá, a mão laboriosa soube humanizar a rude paisagem natural sem a desfigurar." Cf. XIII 150.

${ }^{47}$ Cf. Santos 2010: 64-65.

48 “[...] invocação do 'locus' corresponde a uma estratégia endurecedora da identidade. Um espesso sentimento de indigenato assimila paisagem e Homem." Cf. Vilela 1994: 502.

49 "E graças a Deus que assim acontece, que do Minho ao Algarve toda a paisagem me sabe bem. Sou dos poucos portugueses que se podem gabar de, sempre que como tal se identificam, o serem de Portugal inteiro.” Cf. XIV, 98. 
na paisagem e na língua o seu reduto identitário ${ }^{50}$. Também se podem observar traços de uma heróica ascese laica associada ao esforço, penoso ou não, do trabalhador agrícola que mantém certas paisagens à custa dos seus músculos, e de um lamento sobre quão célere se conspurca Portugal com o abandono rural. Banalização que mais não é do que uma consequência da terciarização económica e da migração urbanizadora, depois do fim da hegemonização da paisagem rural pela agricultura. Todos estes aspectos acarretaram para as décadas finais do século XX um convívio paisagístico forçado entre os destroços de um passado derrelicto e as promessas efémeras de futuro, e a que já não são alheios os propósitos de fruição e utilização consumista das populações urbanas. Juízos sobre a autenticidade pretérita da paisagem correspondem afinal, segundo Domingues, à reacção perante a ruína de referentes estáveis e mitificados ${ }^{51}$. Perante o fantasma do morto, torna-se mais difícil fazer o luto, e daí a presença fantasmática que norteia as sentenças morais acerca dos nexos locais e globais que as paisagens contemporâneas encerram e misturam. Baptista argumenta também no sentido da importância de nos livrarmos do fardo dogmático do passado associado à paisagem rural, para que melhor possamos gerir o presente ${ }^{52}$; afinal, a melhor razão para rejeitarmos as possíveis benesses civilizacionais das virtudes associadas ao campo e à terra é a demonstração cabal do seu malogro e que um contínuo êxodo rural atesta; o elogio dessa condição esteve, de facto, muitas vezes ligado a propósitos e objectivos ideológicos das classes sociais urbanas que beneficiavam com a existência de assalariados, jornaleiros e explorações agrícolas de mão-de-obra intensiva.

As leituras de Domingues e Baptista concebem porém a paisagem como um mero palco dos desígnios económicos e sociais que nela actuam. A crítica que sustentam prende-se com a desconstrução de subjectividades $^{53}$ que intentam recuperar-lhe o seu estatuto vinculativo, e que

50 “[...] De tudo o que fomos, restam-nos apenas a paisagem e a língua. O resto foi-se. As rodas e as asas do progresso, a rádio, o cinema, a televisão [...] subverteram e desfiguraram a nossa realidade social e cultural.” Cf. XIII, 121.

51 “A incompreensão dessa descaracterização faz-se, habitualmente, acompanhar do rol da perda de supostas autenticidades que, de tanto mitificadas, parecem ter pertencido a um tempo primordial, sem história e sem outro referente que não um passado mais-que-perfeito. Nesse passado a vida no campo era a imagem do Paraíso e do bom povo sábio, pobre mas honesto, que vivia na sua simplicidade, alegria, em comunhão com a Natureza e oração com os deuses.” Cf. Domingues 2011: 16.

52 “O território é assim, sobretudo, o passado. Esta atitude tem vindo a impregnar todo o relacionamento com o espaço, não deixando, muitas vezes, detectar as profundas mudanças que nele ocorreram, nem permitindo repensar, com ousadia, o seu futuro." Cf. Baptista 2001.

53 "Quanto à paisagem e à sua modificação - e não a sua estragação, corrupção, descaracterização e outros adjectivos negativos que se reportam sempre a uma 
como tal possam obstar à sua organização e gestão racionais; os autores acautelam para o risco de se conceberem paisagens rurais para lá da sua sustentabilidade financeira, sejam ela agrícolas, pecuárias ou vinícolas. Ambos consagram o papel inevitável da tecnologia na sua crescente feição produtiva perante os mercados e parecem querer resumir a paisagem factualizando e quantificando a cesura actual que a retira do homem. A actual descaracterização e a degradação paisagísticas seriam apenas devaneios estéticos urbanos, e não juízos informados sobre como essa relação sintética que é a paisagem sinaliza um desenraizamento do homem.

Existe de facto no Diário de Torga uma implícita concepção aliando a paisagem à ruralidade e que é robusta o suficiente para objectar a esta visão redutora da paisagem que mantém a separabilidade entre a paisagem objectiva e a fenoménica. Trata-se sobretudo de uma concepção que não faz tábua rasa do cuidado para com a paisagem, assumindo-o como fundamento da condição de habitabilidade humana e social da terra. No Diário é desde logo tácito a permanência de uma íntima reciprocidade e assimilação entre homem e paisagem ${ }^{54}$. Numa entrada, vaticina-se a necessidade de alargamento da noção puramente geográfica de paisagem para outra que inclua nela a subjectividade própria do indivíduo arreiga$\mathrm{do}^{55}$, o qual é valorizado perante aquele somente aculturado; nota-se pois a porosidade do humano a toda a dinâmica biofísica da paisagem, emergindo nas suas posturas, falares, idiossincrasias, o que expõe a noção ontológica da interdependência do ser. Não havendo então separabilidade possível entre homem e paisagem e não sendo possível resumir esta à sua factualidade cognitiva, como abordá-la? Através do reconhecimento do primado da experiência estética, pois que os seus encantos cénicos e matizados permitem, ao invés, dar conta de uma relação com a paisagem de nível mais elevado, onde a reverência e o respeito surgem associados ao sentimento de comunhão ${ }^{56}$.

ordem anterior, a um passado mitificado - a questão baseia-se exactamente não no equilíbrio mas na instabilidade e na ruptura." Cf. Domingues 2011: 146.

54 "Não sei em que medida a paisagem faz o homem. Há várias teorias sobre o caso, mas as teorias cada vez me satisfazem menos. Do que não tenho dúvidas é da íntima ligação que existe entre o deserto e os olhos rasos de desânimo do dromedário que o passeia." Cf. II, 47 e X, 192.

55 " $[. .$.$] que se fizesse do homem um dos elementos fundamentais da geografia [...]$ a par do relevo ou vegetação. Se o meio penetra o homem, é depois o homem que o incarna, o polariza, e testemunha o espírito e a essência do que nele é fundamental e vivo. O indivíduo - o enraizado, claro está - exprime, queira ou não queira, a própria alma do chão que o viu nascer..." Cf. II, 147.

56 "Devo à paisagem as poucas alegrias que tive no mundo. [...] retratar uma folha sem tremer como ela, olhar para um abismo sem fundura nos olhos, é para mim o mesmo que gostar sem língua, ou cantar sem voz. Vivo a natureza integrado nela. 
Há pois em Torga paralelismos com o primado da fenomenologia da vivência de Berleant, que concede à sensação multi-estésica ${ }^{57} \mathrm{o}$ acesso estético-ontológico aos diversos elos relacionais que a paisagem cristaliza. E é por conseguinte lídimo que a consciência dessa assimilação recíproca enforme juízos críticos sobre como as paisagens ${ }^{58}$ que nos ofendem e degradam ${ }^{59}$ assinalam as graves e profundas alterações de que padece a relação do homem com as coisas ${ }^{60}$. No outro termo da degradação, a paisagem surde então como necessária ao processo de auto-gnose do homem, garantia não exaurível da demanda laica pela beatitude; é ela a âncora que fundeia o homem em si mesmo, segredando-lhe através de uma comunhão sensorial com o que o rodeia um deslumbramento humilde de alcance ético. Eis uma passagem ilustrativa e sintética de Miguel Torga a propósito de um percurso pelas serras do Gerês:

Gerês, 10 de Agosto de 1964 - Deixei-me levar passivamente pelas rodas do carro, que percorre a serra em todas as direcções. Dou aos olhos plena liberdade sensorial, sem lhes pedir contas da qualidade das sensações recebidas. Abandono-me à volúpia dum encontro meramente físico com a realidade. Fragas, matas, rios e ribeiros, tudo entra em mim como a luz pelas vidraças. Entra e cabe. Não há imagens no mundo que saciem a pura transparência. Nada entendo, e nada quero entender. E sinto paz. A paz de ser uma simples coisa permeável entre coisas impermeáveis. Paz que o homem primitivo certamente já experimentou, e que talvez seja a que resta ao homem de sempre. Atingir na identificação inconsciente com a natureza a única consciência profunda que dela e de si pode ter. $(\mathrm{X}, 34)$.

De tal modo, que chego a sentir-me, em certas ocasiões, pedra, orvalho, flor ou nevoeiro." Cf. II, 71.

57 "[...] tenho de ser impiedoso e escrever a palavra sanguessuga. Só ela sugere capazmente a monstruosidade do que se passa: um anelídeo humano, de boca em ventosa, a sorver avidamente a paisagem.” Cf. IX, 129.

58 "Lugares outrora visitados e descritos, então de rosto juvenil, apareciam-me agora enrugados, gastos, encanecidos. O mundo parece prostituído. Vilão no seu baldio, a paisagem doméstica devolvia-me a imagem patética de uma velhice também doméstica e apavorante: a da banalização.” Cf. XII, 43.

59 "Num extremo temos algumas paisagens que nos podem proporcionar uma profunda comunhão com a natureza e o espírito; no outro, as paisagens podem aviltar-nos ou ferir-nos. Entre estes dois pólos reside a maioria das nossas experiências ambientais. O juízo crítico articula-se, então, com a apreciação.” Cf. Serrão 2011: 389.

60 "O tempo é outro, as solicitações são outras, as mentalidades são outras. Até a angústia mudou, pois que mudou a relação do homem com as coisas. Um risco abstracto basta agora à exactidão do nosso perfil.” Cf. XIII, 26. 


\section{Conclusão}

Assinalámos como, ao longo do Diário, o termo "paisagem" parece surgir como a substância à qual o autor junge várias qualidades, detalhando-lhe o sentido. Surpreendemos, por exemplo, na entrada presente na nota 46, o adjectivo "natural" aposto a "paisagem", concorrendo para essa síntese bem-sucedida a "mão laboriosa" do trabalho que humaniza a rudeza silvestre. Há, portanto, um reconhecimento da paisagem enquanto articulação da natureza e da cultura e de uma apreciação multisensorial que, em absorvendo cinesticamente a paisagem, pode corroborar a harmonia desse jogo de forças. Existem, contudo, paradoxos; se o autor reconhece em mais do que uma ocasião que o homem está nela embutido, é tanto mais estranho deslindar uma entrada em que testemunhamos que a paisagem, sendo toda natureza, está, para o autor, fora da história huma$\mathrm{na}^{61}$. Encontramos porém uma passagem significativa que nos permite prolongar este exame do sentido da paisagem através do desdobramento dos seus constituintes ${ }^{62}$; envoltas numa cristalização arquetípica que $o$ autor reputa como intemporal, a paisagem "geográfica" e a paisagem "humana" entrelaçam-se para comporem o lar paterno que desperta o poeta do seu estupor céptico e o remoça. Invocando o mito de Anteu ou não, parece-nos verossímil assertar que o recurso à figura regeneradora dos íncolas e das belezas paisagísticas nos arrabaldes do lar de S. Martinho de Anta, ilustram a admoestação de Berleant sobre a urgência do habitar $^{63}$.

Acreditamos pois que, apesar do verbete que a nota 61 assinala, foi possível identificar ao longo deste artigo várias considerações presentes no Diário que denotam uma elevada sensibilidade à beleza e ao sublime paisagísticos e que, embora celebrando algum imobilismo identitário,

61 "Por aqui entraram os castelhanos, os franceses, os trauliteiros... E não consigo ver nada! Os montes, a veiga, o rio e os amieiros continuam impassíveis, a ser, a correr e a crescer. A História nunca abrange a natureza. Felizmente. A paisagem fica sempre de fora dos acontecimentos." Cf. IX, 88-89.

62 "Intemporal e mítica, a paisagem geográfica é nos meus sentidos uma perpétua miragem; quanto à outra, à humana, tais virtudes lhe descubro, que parece que só junto dela sou gente. As raras horas de céptica objectividade são guinadas passageiras. É na exaltação e na confiança que o corpo e o espírito respiram aqui. E cada visita que faço a este chão amado lembra mais uma peregrinação de sonâmbulo do que um contacto acordado." Cf. VII; 65.

63 "Without a somatic attachment to a place, we stand homeless, regardless of our domicile. This bodily awareness of the land often resembles the aesthetic awareness of landscape in being cultivable but largely uncultivated." Cf. Berleant 2005: 100. 
aproximam a noção de paisagem de Torga aos conceitos avançados por $\mathrm{D}^{\prime}$ Angelo ${ }^{64}$ ou Berleant ${ }^{65}$. O autor encara a paisagem como o contexto físico onde se digladiam forças sociais e naturais mas ao qual se sobrepõe a própria subjectividade humana, através da percepção que apreende sensorialmente valores estéticos e éticos. Estamos então longe do vazio conceptual com que Domingues caricatura o conceito de paisagem, mas cuja clarificação surge concomitante às velozes flutuações que a varam ${ }^{66}$.

$\mathrm{O}$ fastio e a tristeza profundas do poeta demonstradas perante o assalto turístico e a corrupção urbanística e biofísica da paisagem assinalam por conseguinte bastante mais do que um desconforto pontual; apontam precisamente para um dos programas que Berleant delineou para a nascente disciplina da estética do ambiente, mormente aquele que cuida como certas paisagens nos ofendem de alguma maneira, através das rupturas que introduzem ${ }^{67}$. Talvez a mudança repentina que as avoengas paisagens citadinas e rurais sofreram recentemente, depois de décadas em que a sua relativa solidez nos convenceu da sua imutabilidade, tenham contribuído para uma visão culturalista que identifica uma certa saúde social com a constância da herança paisagística. Mesmo Berleant reconhece que, perante paisagens em mutação, o referente, a sua substância, se torna mais instável de apreender por quaisquer representações conceptuais, usualmente erigidas antes de tais mudanças se instalarem. A

64 "É necessário chegar a pensar-se a paisagem como identidade estética dos lugares, como um valor certamente não objectivo (dado que nenhum valor estético, nem mesmo o da Divina Comédia, o é), mas não meramente subjectivo no sentido de arbitrariedade. É necessário reivindicar para a paisagem o estatuto de todos os valores estéticos, e que é o de serem valores intersubjectivos, culturais, históricos, isto é, de serem meios de identificação cultural para uma comunidade, para um povo." Cf. Serrão 2012: 340.

65 "Landscape, reflecting the experience of and immediate location, is more particular. It is an individual environment, its peculiar features embodying in a distinctive way the factors that constitute any environment and emphasizing the human presence as the perceptual activator of the environment." Cf. Berleant 1997: 12.

66 "Tudo isto é sinal claro da dificuldade em compreender e gerir a complexidade e a velocidade da mudança que caracterizam a aceleração do tempo em que vivemos: uns inventam conceitos-esponja onde tudo cabe, da escala universal à local, do passado ao futuro: sustentabilidade ou paisagem são dois desses pseudo-conceitos que permitem falar a propósito de quase-tudo.” Cf. Domingues 2011: 156.

67 "The aesthetics of environment must recognize the experience of landscapes that offend us in various ways: by destroying the identity and affection of place, by disrupting architectural coherence, by imposing sounds and smells that may injure as well as repel, by making our living environment hostile and even uninhabitable. Part of this criticism is aesthetics, an offense to our perceptual sensibilities and an immediate encounter with negative value.” Cf. Berleant 1997: 14. 
paisagem, enquanto nexo de intersubjectividade humana e forças naturais, é de facto um "estado transiente de situações e um conceito que identifica um processo de transição" ${ }^{68}$. Longe de estarmos perante um dualismo entre a permanência e a impermanência, trata-se de discutir a qualidade da mudança que as atravessa e que avalizamos como necessária. Neste aspecto, parece-nos que Torga vislumbrou, no desaparecimento das paisagens em que se escarmentou, a ruína da identidade de um certo país que aprendeu durante longos anos a conhecer e a amar ${ }^{69}$.

\section{Referências bibliográficas}

AA.VV., Aqui, Neste Lugar e Nesta Hora - Actas do Primeiro Congresso Internacional Sobre Miguel Torga. Porto: Edições Universidade Fernando Pessoa, 1994.

AA.VV., Miguel Torga e a Literatura Intimista - Actas do Colóquio. Coimbra: Câmara Municipal de Coimbra/Departamento de Cultura, 2005.

AA.VV., Sou um homem de granito - Miguel Torga e seu compromisso. Colóquio Internacional sobre Miguel Torga. Lisboa: Edições Salamandra, 1997.

LEÃO, Isabel Vaz Ponce de, A Obrigação, a Devoção e a Maceração - O Diário de Miguel Torga. Lisboa: Imprensa Nacional-Casa da Moeda, 2005.

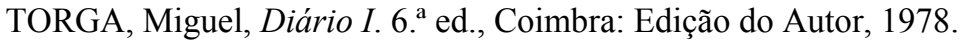
, Diário II. 4. a ed., Coimbra: Edição do Autor, 1977. , Diário III. 2. ${ }^{\mathrm{a}}$ ed. revista, Coimbra: Edição do Autor, 1954. , Diário IV. 3. ${ }^{a}$ ed., Coimbra: Edição do Autor, 1973. , Diário V. 3. ${ }^{a}$ ed. revista, Coimbra: Edição do Autor, 1974. , Diário VI. 2. ${ }^{\text {a }}$ ed. revista, Coimbra: Edição do Autor, 1960. , Diário VII. 2. ${ }^{\mathrm{a}}$ ed. revista, Coimbra: Edição do Autor, 1961. , Diário VIII. 3. ${ }^{a}$ ed. revista, Coimbra: Edição do Autor, 1976. , Diário IX. 1. a ed. revista, Coimbra: Edição do Autor, 1966. , Diário X. 1. a ed., Coimbra: Edição do Autor, 1968. , Diário XI. 1. ${ }^{\mathrm{a}}$ ed., Coimbra: Edição do Autor, 1973. , Diário XII. 2. ${ }^{a}$ ed., Coimbra: Edição do Autor, 1977. , Diário XIII. 1. a ed., Coimbra: Edição do Autor, 1983. , Diário XIV. 1. a ed., Coimbra: Edição do Autor, 1987. , Diário XV. 1. ${ }^{\mathrm{a}}$ ed., Coimbra: Edição do Autor, 1990. Diário XVI. 1. a ed., Coimbra: Edição do Autor, 1993.

${ }^{68}$ Cf. Serrão 2012: 358.

69 "Portugal já nem nos seus lugares emblemáticos, com pergaminhos históricos e naturais, é Portugal. Desfigurado pelo furor dos emigrantes e invadido por ondas de turistas de calção e sandália, só a custo deixa vislumbrar a identidade profunda. A própria paisagem, devassada por milhares e milhares de olhares indiferentes ou alheios, se me afigura murcha e combalida, voltada contra o deslumbramento legítimo de quantos tentam ainda preservá-la e honrá-la.” Cf. XVI, 91. 


\section{Leituras complementares}

BAPTISTA, Fernando Oliveira, Agriculturas e Territórios,. Oeiras, Celta editora, 2001.

BERLEANT, Arnold, Living in the Landscape. Kansas: University Press of Kansas, 1997.

, Aesthetics and Environment. England: Ashgate Publishing Limited, 2005.

CARERI, Francesco, Walkscapes - Camminare Como Pratica Estetica. Roma: Einaudi, 2006.

DOMINGUES, Álvaro, Vida no Campo. Porto: Dafne, 2011.

SANTOS, Henrique Pereira dos, Do tempo e da paisagem. Manual para a leitura de paisagens. Parede: Princípia, 2010

SERRÃO, Adriana Veríssimo (coord.), Filosofia da Paisagem. Uma Antologia. Lisboa: Centro de Filosofia da Universidade de Lisboa, 2011. , Filosofia e Arquitectura da Paisagem. Um Manual. Lisboa: Centro de Filosofia da Universidade de Lisboa, 2012.

\section{RESUMO}

O Diário de Miguel Torga constitui uma obra ímpar no contexto da literatura portuguesa. Publicado em dezasseis volumes ao longo de sessenta anos do século $\mathrm{XX}$, a leitura das suas páginas permite o acesso a vários tópicos reflexivos caros ao autor. Destes, a paisagem assume especial interesse, mormente na originalidade das suas referências entrecruzadas com a escrita, a ruralidade, o corpo, o progresso técnico e Portugal. Não obstante estas considerações acerca da paisagem, o Diário não apresenta nenhuma definição clara e unívoca da mesma.

Perante esta ausência pretendemos, em diálogo com outros autores, tentar surpreender o conceito de paisagem que o autor tinha presente para si mesmo. Por fim, queremos igualmente articular tais tematizações da paisagem com o próprio acto de escrita diarística e o concomitante processo heurístico de auto-gnose. Deverá tornar-se claro como o Diário prefigura uma proposta de apelo e valorização das virtudes concomitantes a um enraizamento telúrico.

Palavras-chave: paisagem, estética ambiental, escrita, corpo, ruralidade, natureza. 


\begin{abstract}
Miguel Torga's Diário constitutes a unique work in the context of Portuguese literature. Divided in 16 volumes published over 60 years of the XX century, Diário gives its reader access to several topics of reflection dear to the author. Among these, the topic of landscape is of particular interest, given the originality of its crisscrossing with writing, rurality, the body, technological progress, and Portugal itself. These considerations notwithstanding, Diário does not present a clear and univocal definition of landscape.

Given this absence, it is our goal to grasp, in dialogue with other authors, the concept of landscape which Torga himself had in mind. Finally, we will attempt to articulate Torga's reflections on landscape with the act of diary writing and the related heuristic process of self-gnosis. In consequence, the way in which Diário foreshadows a call for and a valorization of the virtues accompanying a telluric rooting should become clear.
\end{abstract}

Keywords: landscape, environmental aesthetics, writing, body, rurality, nature. 